doc.dr inz. Jerzy Nowicki

mgr inz. Sienicki Adam

Instytut Pojazdów Szynowych „TABOR”

\title{
Parametry o istotnym wpływie na sily poprzecznego oddziaływania na tor lokomotyw z dwu- i trójosiowymi wózkami jezdnymi oraz wytyczne do modernizacji tych wózków
}

\begin{abstract}
W opracowaniu omówiono geneze problemu nadmiernych oddziaływań na tory wybranych polskich lokomotyw 4-ro i 6-cio osiowych, opisano oraz zestawiono liste parametrów majacych istotny wptyw na to zjawisko. Niektóre z tych parametrów majq istotne znaczenie podczas szybkiej jazdy na odcinkach prostych, a inne na tukach torowych o matych promieniach. Przedstawiono też zakresy tych parametrów konieczne do uzyskania znaczacej poprawy właściwości biegowych $w$ ramach przewidywanych lub przeprowadzonych $w$ ostatnim czasie modernizacji lokomotyw o dużm znaczeniu gospodarczym dla Polski.
\end{abstract}

\section{Wstęp}

Większość pojazdów trakcyjnych eksploatowanych w Polsce charakteryzuje zbyt wysoki poziom sił poprzecznego oddziaływania na tor, co obniża ich bezpieczeństwo ruchu, podwyższa koszty eksploatacyjne i uniemożliwia ich wykorzystanie w ruchu w obszarze Unii Europejskiej. Zagadnienie to, regulowane od pewnego czasu zharmonizowaną normą PN EN - 14363 [1], w trybie obligatoryjnym zaostrzało dotychczas obowiązujące kryteria homologacyjne nowobudowanych pojazdów szynowych i wykorzystywane 
jest jako argument w trakcie wnioskowania przez stronę polską o dopuszczenie naszych lokomotyw do ruchu tranzytowego w krajach unijnych.

\section{Merytoryczny zakres proponowanych moderni- zacji}

Dla realizacji zadania ważnym problemem stało się rozwiązanie trudnych i złożonych zagadnień teoretycznych, obejmujących modelowanie układów prowadzenia $\mathrm{w}$ torze i zawieszenia wózków i nadwozi pojazdów trakcyjnych $[2,3,4,5,6]$. Powyższe zagadnienia stały się podstawowymi tematami realizowanymi w ramach projektu badawczego nr N N509 286435 pt. "Optymalizacja poprzecznych sit prowadzacych krajowych pojazdów trakcyjnych umożliwiajaca ich wykorzystanie $w$ międzynarodowym ruchu europejskim", którego celem było poznanie i ocena wpływu różnych rozwiązań konstrukcyjnych na siły poprzeczne prowadzące zestawy kołowe tych pojazdów, poprzez budowę i opis matematyczny modeli tych pojazdów szynowych uwzględniających:

- różnoraki układ osi (np. Bo-Bo, Bo-Bo-Bo, Co-Co itd.),

- różnorodne rozwiązania konstrukcyjne prowadzeń zestawów kołowych, układów zawieszeń wózków i nadwozi,

- różnorodne sprzężenia poprzeczne między zestawami kołowymi lub ich grupami podczas działania sił koło-szyna,

- współpracę koła z szyną z uwzględnieniem najczęściej spotykanych profili roboczych i stanów czystości powierzchni kontaktowych wpływających na wartości sił stycznych.

Okazało się, że lokomotywy z wózkami dwuosiowymi nie spełniają kryterium stateczności biegu, a tym samym nie mają wystarczającej spokojności jazdy. Stwierdzenie to skierowało obliczenia na określenie wpływu dodatkowych urządzeń thumiących drgania obrotowe wózków, takie jak thumiki wężykowania lub boczne ślizgi cierne wózków - nadwozie. Dało to oczekiwane rezultaty, lecz dopiero po zastosowaniu dużych sztywności ich mocowania do korpusów bazowych. Po zastosowaniu takich rozwiązań nie można jednak uzyskać prędkości eksploatacyjnych większych niż $200 \mathrm{~km} / \mathrm{h}$.

Natomiast w lokomotywach z wózkami trójosiowymi, które generalnie nie nadają się do eksploatacji z prędkościami powyżej $140 \mathrm{~km} / \mathrm{h}$, co potwierdziły wyniki obliczeń, wystapiły nadmierne siły poprzeczne prowadzące wózki $\mathrm{w}$ torze na łukach i towarzyszące im ryzyko wykolejenia przedniego zestawu kołowego.

Jakościowo zjawisko to jest znane od dawna, a wyniki obliczeń symulacyjnych uzyskanych w ramach realizacji projektu pozwoliły na ocenę ilościową.

Uwzględniając różne kombinacje parametrów zawieszenia i prowadzenia wózków, wytypowano kilka rozwiązań, jako ważniejsze koncepcje modyfikacji tych węzłów, dla badanych lokomotyw:
- propozycja zastosowania sprzęu miedzywózkowego,

- polepszenie podatności prowadzenia w płaszczyźnie poprzecznej do osi toru środkowych zestawów kołowych w wózkach trójosiowych, co dało by możliwość spełnienia wymagań TSI [7], przy czym praktycznie wprowadzenie tej w ramach prostych modernizacji może się okazać trudne,

- zupełnie nowym rozwiązaniem obniżającym poprzeczne oddziaływanie na tor wózków trzyosiowych jest propozycja zastosowania mikroprocesorowego, aktywnego sterowania skrętem tych wózków podczas ruchu w łukach torowych i krzywych przejściowych, za pomocą sygnałów pochodzących od krzywizn toru w planie, np. poprzez wykorzystanie sygnałów od poprzecznych przyspieszeń quasistatycznych występujących na zestawie kołowym prowadzącym lub sygnałów o wartościach sił łożyskowych.

Ponadto opracowano następujące propozycje modyfikacji zawieszeń lokomotyw dla spełnienia wymagań wynikających z norm zharmonizowanych:

- Modernizacja zawieszenia II-go stopnia na lokomotywach z wózkami trójosiowymi ET22 i SU46/45 na zawieszenia bardziej podatne na odkształcenia poprzeczne i pionowe dla obniżenia momentów oporowych między wózkiem, a nadwoziem dla poprawy bezpieczeństwa przed wykolejeniem oraz dla obniżenia sił poprzecznych oddziaływania na tor,

- na lokomotywie ET 22 zaproponowano zmianę podparć gumowych z 5020 na usprężynowanie sprężynami stalowymi wielkogabarytowymi oraz wprowadzenie układu siłowników hydraulicznych dla poprawy (podwyższenia) pionowych nacisków zestawów kołowych podczas rozruchu trakcyjnego,

- w zawieszeniu II-go stopnia lokomotywy SU46/45 wprowadzono piątą podporę gumowa dla poprawy rozkładu pionowych nacisków zestawów kołowych,

- modernizacja zawieszenia II-go stopnia na lokomotywach z wózkami dwuosiowymi EU07 i EP09 w celu zwiększenia ich podatności szczególnie w kierunku pionowym, dla poprawy bezpieczeństwa i spokojności jazdy,

- w lokomotywie EU07 wprowadzono teflonowe płytki ślizgowe $\mathrm{w}$ miejsce stalowych $\mathrm{w}$ podparciach bocznych nadwozia na wózkach dla obniżenia bocznych przyspieszeń. Wprowadzono napięcie wstępne sprężyn w wyżej wymienionych podparciach dla obniżenia współczynnika kołysania nadwozia, jak również dla obniżenia przyspieszeń. 
Dla poprawy w/w parametrów ponadto wprowadzono:

- stabilizator kołysania nadwozia (drążek stabilizujący),

- silne pionowe tłumiki hydrauliczne wózek-nadwozie,

- tłumiki wężykowania dla uzyskania stabilności ruchu dla prędkości powyżej 140 $\mathrm{km} / \mathrm{h}$.

- na lokomotywie EP09 wprowadzono sprężyny śrubowe wielkogabarytowe.

Modernizacja zawieszenia I-go stopnia wózków trójosiowych, jaki dwuosiowych dla lokomotyw ET22, SU46, EU07, EP09, ST43 oraz BR 232 zmierzająca do zwiększenia ich podatności i obniżenia oporów tarcia przy pionowych ugięciach układu sprężynowania, dla poprawy bezpieczeństwa i spokojności jazdy.

- na lokomotywie ET22 w miejsce sytemu resorowo - wahaczowego wprowadzono sprężyny śrubowe oraz pionowe tłumiki hydrauliczne oparte na maźnicach skrzydełkowych,

- w zawieszeniu lokomotywy SU46/45 zwiększono elastyczność systemu resorowowahaczowego przez dodanie sprężyn śrubowych nad resorami piórowymi.

Ponadto na tej lokomotywie wprowadzono bardzo elastyczne prowadzenie poprzeczne środkowych osi wózków w celu obniżenia poprzecznych sił $\mathrm{H}$ występujących na łukach i rozjazdach,

- na lokomotywie EU07 nad resorami dodano przekładki gumowe dla poprawy pionowych nacisków na koła podczas jazdy po torze zwichrowanym.

Propozycje zmian wprowadzone do rozpatrywanych lokomotyw, na podstawie oceny uzyskanych wyników obliczeń, dają następujący obraz:

- zastosowanie sprzęgu między-wózkowego na lokomotywach typu Bo-Bo (EU07, EP09) wydatnie zmniejszyło wskaźnik bezpieczeństwa przed wykolejeniem na zwichrowanych łukach torowych i zmniejszyło także poprzeczne oddziaływanie kół lokomotyw na szyny w łukach,

- wprowadzenie tłumików wężykowania zarówno na lokomotywach typu Bo-Bo i Co-Co pozwala na zwiększenie prędkości eksploatacyjnej o 20 - $80 \mathrm{~km} / \mathrm{h}$ dzięki poprawie stateczności biegu wózków,

- zmodernizowanie II-go stopnia usprężynowania nadwozi lokomotyw znacząco poprawia spokojność jazdy i bezpieczeństwo przed wykolejeniem lokomotyw typu Bo-Bo i Co-Co bez szkodliwych skutków ubocznych dla oddziaływania na tor w łukach,
- zmodernizowanie zawieszenia I-go stopnia poprawia głównie znacząco bezpieczeństwo przed wykolejeniem lokomotyw. Przy czym pozostałe wskaźniki dynamiczne (oddziaływanie na tor, wskaźnik spokojności biegu) ulegają niewielkim niekorzystnym zmianom,

- modernizacja prowadzenia poprzecznego wzdłużnego zestawów kołowych lokomotyw typu Co-Co poprzez usztywnienie prowadników maźnic osi skrajnych i uelastycznienie prowadników osi środkowych wprowadziła istotną poprawę oddziaływania wózków na tor w łukach i odcinkach prostych, a ponadto istotnie, korzystnie wpłynęła na spokojność biegu i na stateczność,

- mechatroniczne sterowanie kątem obrotu wózków względem pudła w lokomotywach typu Bo-Bo oraz Co-Co daje znakomite efekty oddziaływania zestawów kołowych na tory zakrzywione, bez istotnych efektów ubocznych (np. na stateczność biegu). Zagadnienie to wymaga jednak dalszych studiów teoretycznych i badań doświadczalnych, zanim można będzie je proponować do zastosowania w praktyce produkcyjnej.

\section{Zestawienie parametrów o istotnym wpływie na własności dynamiczne badanych lokomotyw}

Przeprowadzone obliczenia symulacyjne i analizy uzyskanych wyników wyłoniły, następujące istotne parametry układu biegowego lokomotyw w odniesieniu do jakości biegu, spokojności jazdy, oddziaływania na tor i bezpieczeństwa ruchu.

+ Lokomotywa EU07(A):

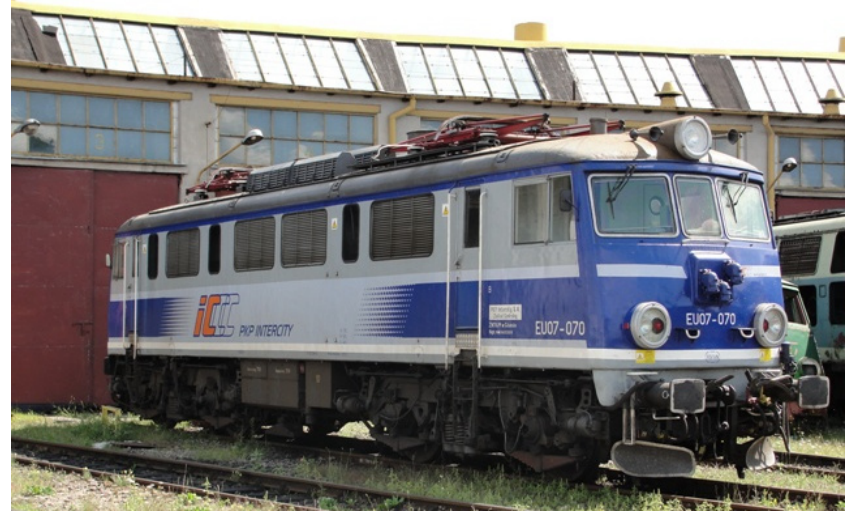

- w zespole zawieszenia I-go stopnia:

- sztywność pionowa resorowania maźniczego w aspekcie sprężynach nadresorowych,

- sztywność pionowa samego resoru piórowego,

- współczynnik tarcia między piórami resorów,

- sztywność pionowa prowadników zestawów kołowych typu Alstom,

- sztywność poprzeczna prowadników zestawów kołowych typu Alstom,

- luzy poprzeczne w łożyskach maźniczych, 
- w zespole zawieszenia II-go stopnia:

- sztywność pionowa zawieszenia nadwozia na ramie wózka,

- sztywność na kołysanie nadwozia względem ramy wózka,

- współczynnik tarcia na ślizgach oparć bocznych nadwozia na belce bujakowej,

- siła napięcia wstępnego pionowych oparć bocznych, jako blokada kołysania nadwozia na wózkach,

- charakterystyka poprzeczna elastomerowych zderzaków pudło - wózek,

- charakterystyka poprzecznych i pionowych thumików hydraulicznych.

+ Lokomotywa SU/ST45-46:
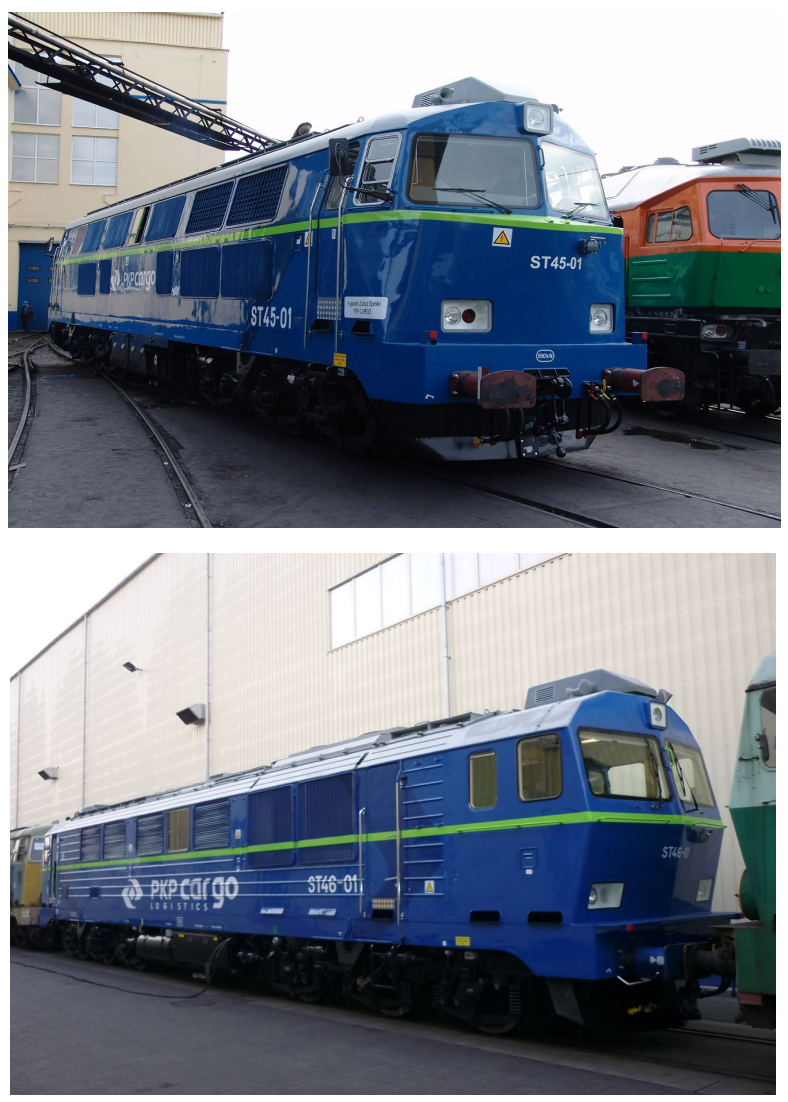

- w zespole zawieszenia I-go stopnia:

- sztywność pionowa resorowania maźniczego w sprężynach nadresorowych,

- sztywność pionowa samego resoru piórowego,

- współczynnik tarcia między piórami resorów,

- $\quad$ sztywność pionowa prowadników zestawów kołowych typu Alstom,

- sztywność poprzeczna prowadników zestawów kołowych typu Alstom,

- luzy poprzeczne w łożyskach maźniczych,

- w zespole zawieszenia silników trakcyjnych względem ramy wózka i zestawów kołowych:

- sztywność poprzeczna prowadników silnika,

- wielkość luzów poprzecznych na panewkach łożysk ślizgowych oparcia silnika-przekładni trakcyjnej na osi zestawu kołowego,
- sztywność poprzeczna i pionowa amortyzatorów w zawieszeniu "za nos" na ramie wózka,

- współczynniki tłumienia $\mathrm{w} \mathrm{w} / \mathrm{w}$ prowadzeniu względem ramy wózka,

- w zespole zawieszenia II-go stopnia:

- sztywność pionowa podparć nadwozia na ramie wózka,

- sztywność poprzeczna podparć nadwozia na ramie wózka,

- sztywność blokady obrotu wózka przed galopowaniem względem osi poprzecznej (siłowniki hydrauliczne),

- charakterystyka poprzeczna elastomerowych zderzaków pudło - wózek,

- charakterystyka poprzecznych i pionowych thumików hydraulicznych.

+ Lokomotywa ET22-2000:

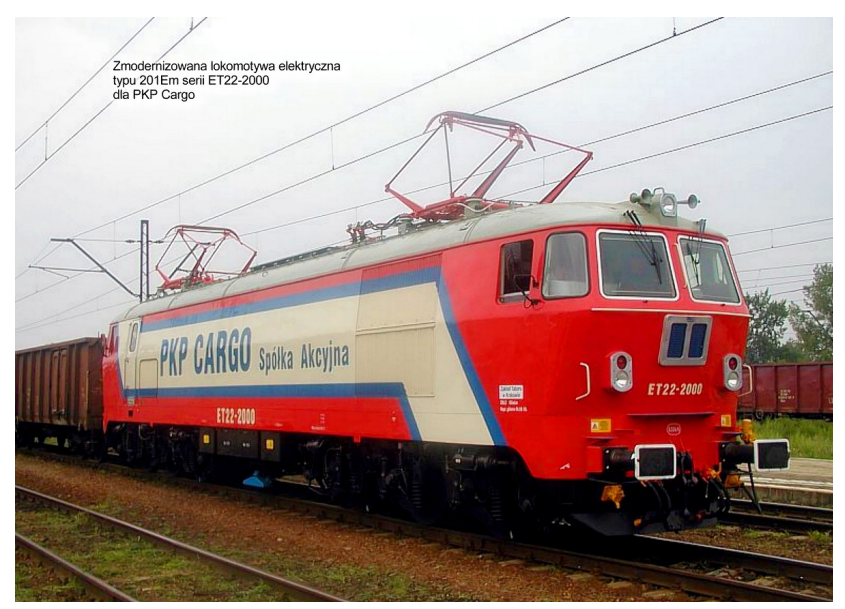

- w zespole zawieszenia I-go stopnia:

- sztywność pionowa resorowania maźniczego w sprężynach nadresorowych,

- sztywność pionowa samego resoru piórowego,

- współczynnik tarcia między piórami resorów,

- sztywność pionowa prowadników zestawów kołowych Alstom,

- sztywność poprzeczna prowadników zestawów kołowych Alstom,

- luzy poprzeczne w łożyskach maźniczych,

- w zespole zawieszenia II-go stopnia:

- sztywność pionowa podparć nadwozia na ramie wózka,

- sztywność poprzeczna podparć nadwozia na ramie wózka,

- sztywność blokady obrotu wózka przed galopowaniem względem osi poprzecznej (siłowniki hydrauliczne),

- charakterystyka poprzeczna elastomerowych zderzaków pudło - wózek,

- charakterystyka poprzecznych i pionowych tłumików hydraulicznych. 


\section{+ Lokomotywa E6ACT:}

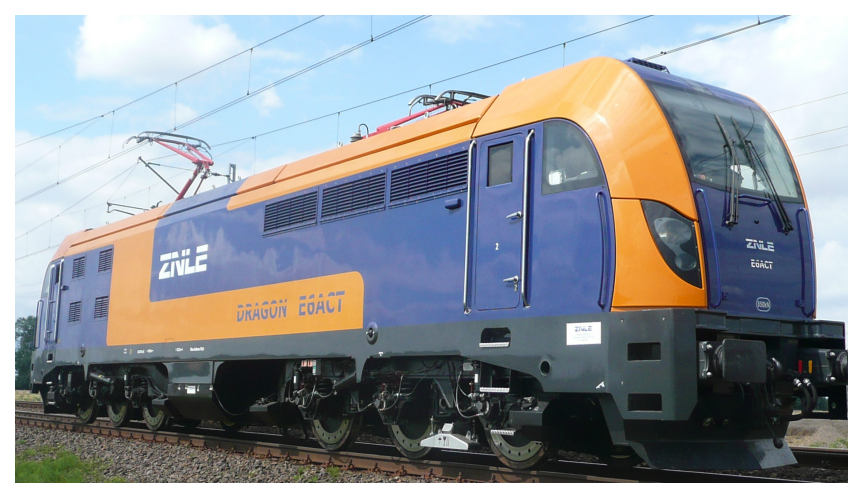

- w zespole zawieszenia I-go stopnia:

- sztywność pionowa sprężyn śrubowych węzła maźniczego,

- sztywność poprzeczna prowadników zestawów kołowych typu Alstom,
- charakterystyka pionowych thumików hydraulicznych,

- w zespole zawieszenia silników trakcyjnych względem ramy wózka i zestawów kołowych:

- sztywność poprzeczna i pionowa amortyzatorów w zawieszeniu "za nos" na ramie wózka,

- współczynników tłumienia w w/w prowadzeniu względem ramy wózka,

- w zespole zawieszenia II-go stopnia:

- sztywność pionowa podparć nadwozia na ramie wózka,

- sztywność poprzeczna podparć nadwozia na ramie wózka,

- charakterystyka poprzeczna elastomerowych zderzaków pudło - wózek,

- charakterystyka poprzecznych i pionowych tłumików hydraulicznych.

\section{Zakresy modernizacji oraz parametry zespołów po zmianach}

\begin{tabular}{|c|c|c|c|}
\hline L.p. & $\begin{array}{c}\text { Rodzaj } \\
\text { lokomotywy }\end{array}$ & $\begin{array}{l}\text { Proponowany zakres } \\
\text { modernizacji }\end{array}$ & Wskazane parametry do modernizacji \\
\hline 1 & 2 & 3 & 4 \\
\hline 1 . & $\begin{array}{c}\text { Lokomotywy z } \\
\text { wózkami } \\
\text { trójosiowymi }\end{array}$ & $\begin{array}{l}\text { - Modernizacja } \\
\text { zawieszenia II-go stopnia }\end{array}$ & Zawieszenie jednego wózka na czterech podporach \\
\hline 1.1 . & $\begin{array}{c}\text { ET } 22[8], \\
\text { SU45/46 [9] }\end{array}$ & $\begin{array}{l}\text {-Zmiana podparć } \\
\text { gumowych Z502a na } \\
\text { uspreżynowanie } \\
\text { spreżynami stalowymi } \\
\text { wielkogabarytowymi } \\
\text { oraz wprowadzenie } \\
\text { układu siłowników } \\
\text { hydraulicznych } \\
\text { (rozwiazzanie realizowane } \\
\text { w lokomotywie ET22- } \\
\text { 2000) }\end{array}$ & $\begin{array}{l}\text { - Parametry, których wprowadzenie umożliwia uzyskanie } \\
\text { większej podatności na odkształcenia poprzeczne i } \\
\text { pionowe dla poprawy bezpieczeństwa przed } \\
\text { wykolejeniem oraz obniżenia sił poprzecznego } \\
\text { oddziaływania na tor: } \\
\text { - sztywność poprzeczna pojedynczych podpór z wartości } \\
0.20 \div 0.40 \text { powinna zostać zmniejszona na wartości z } \\
\text { zakresu } 0.05 \div 0.15 \mathrm{kN} / \mathrm{mm}, \\
\text { - sztywność pionowa pojedynczych podpór z wartości } 2.3 \div \\
3.0 \text { powinna zostać zmniejszona na wartości z zakresu } \\
0.3 \div 0.5 \mathrm{kN} / \mathrm{mm}, \\
\text { - zwiększenie thumienia w kierunku poziomym i pionowym } \\
\text { uzyskać przez dodatkowe thumiki hydrauliczne, } \\
\text { - ewentualny niedobór siły poprzecznej dla większych } \\
\text { wychyleń nadwozia zrealizować poprzez zastosowanie } \\
\text { progresywnych zderzaków elastomerowych, } \\
\text { - niedobór sztywności obrotowej układu podparć należy } \\
\text { uzupełnić sztywnością realizowana przez pionowe } \\
\text { siłowniki hydrauliczne, załączane podczas rozruchu sił } \\
\text { trakcyjnych. Siłowniki należy mocować na końcach ram } \\
\text { wózków i połączyć ich układy olejowe w system } \\
\text { "diagonalny". }\end{array}$ \\
\hline 1.2 . & SU $45 / 46$ & $\begin{array}{l}\text {-Wprowadzenie piątej } \\
\text { podpory gumowej lub } \\
\text { sprężyny śrubowej dla } \\
\text { poprawy rozkładu } \\
\text { pionowych nacisków } \\
\text { zestawów kołowych }\end{array}$ & $\begin{array}{l}\text { - sztywność poprzeczna dodatkowych podpór o } \\
\text { wartościach z zakresu } 0.05 \div 0.25 \mathrm{kN} / \mathrm{mm} \\
\text { - sztywność pionowa dodatkowych podpór o wartościach z } \\
\text { zakresu } 0.25 \div 2.5 \mathrm{kN} / \mathrm{mm}\end{array}$ \\
\hline
\end{tabular}




\begin{tabular}{|c|c|c|c|}
\hline L.p. & $\begin{array}{c}\text { Rodzaj lokomo- } \\
\text { tywy }\end{array}$ & $\begin{array}{l}\text { Proponowany zakres mo- } \\
\text { dernizacji }\end{array}$ & Wskazane parametry do modernizacji \\
\hline 1 & 2 & 3 & 4 \\
\hline \multirow[t]{2}{*}{1.3} & E6ACT & $\begin{array}{l}\text {-Zmiana parametrów } \\
\text { sprężyn i zainstalowa- } \\
\text { nie odbijaków po- } \\
\text { przecznych } \\
\text { (zmiany wprowadzone na } \\
\text { prototypie tej lokomo- } \\
\text { tywy w 2011r) }\end{array}$ & $\begin{array}{l}\text {-Wprowadzenie parametrów zwiększających podatność za- } \\
\text { wieszenia w kierunku poprzecznym i obniżenie oporów } \\
\text { skrętu wózków oraz podwyższenie pionowych ugięć ukła- } \\
\text { du sprężynowania dla poprawy bezpieczeństwa i spokojno- } \\
\text { ści jazdy: } \\
\text { - sztywność poprzeczna pojedynczych podpór z wartości } 0.60 \\
\div 0.80 \text { powinna zostać zmniejszona na wartości z zakresu } \\
0.05 \div 0.25 \mathrm{kN} / \mathrm{mm} \text {, } \\
\text { - sztywność pionowa pojedynczych podpór z wartości } 0.5 \div \\
0.8 \text { powinna zostać zmniejszona na wartości z zakresu } 0.2 \\
\div 0.4 \mathrm{kN} / \mathrm{mm} \text {, } \\
\text { - ewentualny niedobór siły poprzecznej dla realizacji więk- } \\
\text { szych wychyleń nadwozia zrealizować poprzez zastosowa- } \\
\text { nie progresywnych zderzaków elastomerowych, } \\
\text { - zmiana skoku roboczego tłumików hydraulicznych piono- } \\
\text { wych i poprzecznych, }\end{array}$ \\
\hline & & $\begin{array}{l}\text {-Modernizacja zawiesze- } \\
\text { nia I-ego stopnia }\end{array}$ & \\
\hline 1.4 & ET 22 & $\begin{array}{l}\text {-Wprowadzenie - w miej- } \\
\text { sce systemu wahaczo- } \\
\text { wego sprężyn śrubo- } \\
\text { wych lub elastomero- } \\
\text { wych nad resorami } \\
\text { piórowymi, } \\
\text {-Wprowadzenie bardzo } \\
\text { elastycznych prowad- } \\
\text { ników maźnic w kie- } \\
\text { runku pionowym, } \\
\text {-Wprowadzenie - w miej- } \\
\text { sce systemu wahaczo- } \\
\text { wego sprężyn śrubo- } \\
\text { wych lub elastomero- } \\
\text { wych zamiast resorów } \\
\text { piórowych (rozwiąza- } \\
\text { nie lokomotywy ET22- } \\
\text { 2000) }\end{array}$ & $\begin{array}{l}\text { - sztywność pionowa kompletów sprężyn o wartościach } 0.2 \\
\div 1.0 \mathrm{kN} / \mathrm{mm} \text {, } \\
\text { - sztywność pionowa przegubów prowadników realizująca } \\
\text { sztywność pionową na węzeł maźniczy w zakresie } 0 \div 0.4 \\
\mathrm{kN} / \mathrm{mm} \text { przy niezmienionej znacząco sztywności po- } \\
\text { przecznej. } \\
\text { - sztywność pionowa sprężyn w węźle maźniczym o warto- } \\
\text { ściach } 0.60 \div 1.6 \mathrm{kN} / \mathrm{mm} \text {, } \\
\text { - sztywność poprzeczna sprężyn w węźle maźniczym o war- } \\
\text { tościach } 6 \div 30 \mathrm{kN} / \mathrm{mm}\end{array}$ \\
\hline 1.5 & SU $46 / 45$ & $\begin{array}{l}\text {-Zwiększenie elastyczno- } \\
\text { ści systemu resorowo- } \\
\text { wahaczowego przez } \\
\text { dodanie sprężyn śru- } \\
\text { bowych nad resorami } \\
\text { piórowymi }\end{array}$ & $\begin{array}{l}\text { - sztywność pionowa przegubów prowadników realizująca } \\
\text { sztywność pionową w węźle maźniczym z zakresu } 0 \div 0.4 \\
\mathrm{kN} / \mathrm{mm} \text {, przy niezmienionej znacząco sztywności po- } \\
\text { przecznej, } \\
\text { - sztywność pionowa sprężyn w węźle maźniczym } 0.60 \div 1.6 \\
\mathrm{kN} / \mathrm{mm} \text {, } \\
\text { - sztywność poprzeczna sprężyn w węźle maźniczym } 6 \div 30 \\
\mathrm{kN} / \mathrm{mm} \text {. }\end{array}$ \\
\hline 1.6. & SU 46/45 & $\begin{array}{l}\text {-Wprowadzenie bardzo } \\
\text { elastycznego prowa- } \\
\text { dzenia poprzecznego } \\
\text { środkowych osi wóz- } \\
\text { ków dla obniżenia po- } \\
\text { przecznych sił H wy- } \\
\text { stępujących na łukach i } \\
\text { rozjazdach (wprowa- } \\
\text { dzono na zmodernizo- } \\
\text { wanej lokomotywie } \\
\text { ST46) }\end{array}$ & $\begin{array}{l}\text { - sztywność poprzeczna przegubów prowadników realizująca } \\
\text { sztywność poprzeczną na węzeł maźniczy z zakresu } 0 \div 0.5 \\
\text { kN/mm, przy ograniczonej z góry sztywności pionowej. } \\
\text { - prowadzenie poprzeczne silników trakcyjnych względem } \\
\text { ram wózków przeniesione ze sztywnych cięgieł na dodat- } \\
\text { kowe poprzeczne tłumiki hydrauliczne. }\end{array}$ \\
\hline
\end{tabular}




\begin{tabular}{|c|c|c|c|}
\hline 2. & $\begin{array}{l}\text { Lokomotywy z } \\
\text { wózkami } \\
\text { dwuosiowymi }\end{array}$ & $\begin{array}{l}\text {-Modernizacja } \\
\text { zawieszenia II-go } \\
\text { stopnia }\end{array}$ & \begin{tabular}{|ccc}
-Parametry dla zwiększenia podatności zawieszenia \\
głównie w kierunku pionowym, dla poprawy \\
bezpieczeństwa i spokojności jazdy
\end{tabular} \\
\hline 2.1. & EU 07 & $\begin{array}{l}\text {-Wprowadzenie } \\
\text { teflonowych płytek } \\
\text { ślizgowych w miejsce } \\
\text { stalowych w } \\
\text { podparciach bocznych } \\
\text { nadwozia na wózkach } \\
\text { dla obniżenia } \\
\text { przyspieszeń bocznych } \\
\text {-Wprowadzenie napięcia } \\
\text { wstępnego sprężyn w } \\
\text { wyżej wymienionych } \\
\text { podparciach dla } \\
\text { obniżenia wartości } \\
\text { współczynnika } \\
\text { kołysania nadwozia, co } \\
\text { również obniży } \\
\text { przyspieszenia boczne } \\
\text { - Ponadto zaleca się } \\
\text { wprowadzenie: } \\
\text { •stabilizatora kołysania } \\
\text { nadwozia (drążek } \\
\text { stabilizujący) } \\
\text { • pionowych tłumików } \\
\text { hydraulicznych } \\
\text { pomiędzy wózkiem a } \\
\text { nadwoziem } \\
\text { •tłumiki wężykowania } \\
\text { dla uzyskania } \\
\text { stabilności ruchu dla } \\
\text { prędkości powyżej } \\
\text { 140 km/h }\end{array}$ & $\begin{array}{l}\text { - podparcia boczne stabilizujące nadwozie przed } \\
\text { kołysaniem wyposażone w ultra śliskie płytki cierne o } \\
\text { wartości współczynnika tarcia } 0.01 \div 0.05 \text {, } \\
\text { - sprężyny pionowe podparć bocznych napięte wstępnie i } \\
\text { zablokowane } \mathrm{z} \text { tym napięciem o wartościach } 10 \div 20 \mathrm{kN} \text { - } \\
\text { ochrona przed nadmiernym kołysaniem nadwozia na } \\
\text { torach prostych, } \\
\text { - pionowe tłumiki hydrauliczne z zastosowaniem wysokich } \\
\text { wartości tłumienia ( }>150 \mathrm{kNs} / \mathrm{m}) \mathrm{w} \text { celu blokady } \\
\text { kołysania, } \\
\text { - stabilizatory kołysania o sztywności pionowej odniesionej } \\
\text { do ramienia bocznego o wartości } 0.7 \div 1.2 \mathrm{kN} / \mathrm{mm} \text {, } \\
\text { - podłużne tłumiki hydrauliczne } \mathrm{z} \text { zastosowaniem wysokich } \\
\text { wartości tłumienia ( }>500 \mathrm{kNs} / \mathrm{m}) \mathrm{w} \text { celu blokady } \\
\text { wężykowania wózków, }\end{array}$ \\
\hline 2.2 . & EP 09 & $\begin{array}{l}\text {-Wprowadzenie } \\
\text { wielkogabarytowych } \\
\text { sprężyn śrubowych i } \\
\text { tłumików wężykowania } \\
\text { w miejsce } \\
\text { wieszakowego układu } \\
\text { sprężynowania } \\
\text {-Modernizacja } \\
\text { zawieszenia I-go } \\
\text { stopnia }\end{array}$ & $\begin{array}{l}\text { - sztywność poprzeczna pojedynczych sprężyn o wartości z } \\
\text { zakresu } 0.05 \div 0.25 \mathrm{kN} / \mathrm{mm} \text {, } \\
\text { - sztywność pionowa pojedynczych sprężyn o wartości z } \\
\text { zakresu } 0.2 \div 0.4 \mathrm{kN} / \mathrm{mm} \text {, } \\
\text { - podłużne tłumiki hydrauliczne z zastosowaniem wysokich } \\
\text { wartości tłumienia (> }>500 \mathrm{kNs} / \mathrm{m}) \text { w celu hydraulicznej } \\
\text { blokady wężykowania wózków, }\end{array}$ \\
\hline 2.3 & EU 07 & $\begin{array}{l}\text {-Dodanie nad resorami } \\
\text { przekładek gumowych } \\
\text { lub maźnic } \\
\text { skrzydełkowych ze } \\
\text { sprężynami śrubowymi } \\
\text { oraz obniżenie } \\
\text { sztywności pionowej } \\
\text { prowadników maźnic } \\
\text { dla poprawy } \\
\text { pionowych nacisków } \\
\text { na koło na torze } \\
\text { zwichrowanym } \\
\end{array}$ & $\begin{array}{l}\text { - sztywność pionowa przegubów prowadników realizująca } \\
\text { sztywność pionową na węzeł maźniczy z zakresu } 0 \div 0.4 \\
\mathrm{kN} / \mathrm{mm} \text { przy niezmienionej znacząco sztywności } \\
\text { poprzecznej, } \\
\text { - sztywność pionowa sprężyn na węzeł maźniczy } 0.60 \div 1.6 \\
\mathrm{kN} / \mathrm{mm} \text {, } \\
\text { - sztywność poprzeczna sprężyn na węzeł maźniczy } \\
\text { utrzymać w wartościach } 6 \div 30 \mathrm{kN} / \mathrm{mm} \text {. }\end{array}$ \\
\hline
\end{tabular}




\section{Literatura.}

[1] Norma Europejska. EN-14363:2002. Kolejnictwo. Badania własności dynamicznych dla dopuszczenia (homologacji) pojazdów szynowych. Badania własności biegowych i próby stacjonarne.

[2] J. Kisilowski. Dynamika układu mechanicznego pojazd szynowy - tor. PWN Warszawa 1991.

[3] J. J. Kalker. A Fast Algorithm for the Simplified Theory of Rolling Contact. Vehicle System Dynamics 11 (1982).

[4] Carter, F. W.. On the action of a locomotive driving wheel. Proc. Roy. Soc. Lond. Ser A, 112, 151-157, 1926.

[5] Vermeulen, P. J. and Johnson, K. L.. Contact of nonspherical elastic bodies transmitting tangenial forces. Trans. ASME, 1964.

[6] Jaschinski, A. Chollet, H. Iwnicki, S.D. Wickens, A. $H$., Von Wurzen J. The application of roller rigs to railway vehicle dynamics. Veh. Syst. Dyn., 31,345392, 1999.
[7] Dziennik Urzędowy Unii Europejskiej (2008/232/WE). TSI - specyfikacja techniczna interoperacyjności podsystemu „Tabor” transeuropejskiego systemu kolei dużych prędkości.

[8] TTS 11/2004. Konrad Gawłowski. Założenia $i$ koncepcja modernizacji lokomotywy elektrycznej serii ET22.

[9] S. Piatek, S. Węclewski, J. Żałopa. Lokomotywy spalinowe serii SP45. W. K. i Ł. Warszawa 1977.

[10] H. Maciszewski, J. Pawlus, S. Sumiński. Lokomotywy elektryczne serii EU06 $i$ EU07. W. K. $i$ t. Warszawa 1973.

[11] Z. Marciniak, A. Sienicki. Pojazdy Szynowe 1/2000. Analiza pracy układu biegowego lokomotywy EP 09 (104E) w aspekcie poprawy dynamiki podtużnej i trwałości układu napędowego.

[12] E6ACT Dragon w IPS Tabor (pol.). Rynek Kolejowy, 22 marca 2010. 